\title{
METHYL GALLATE FROM JIRINGA (ARCHIDENDRON JIRINGA) AND ANTIOXIDANT ACTIVITY
}

\author{
MISRI YANTY LUBIS ${ }^{1,2 *}$, RIKSON SIBURIAN ${ }^{2,3,4}$, LAMEK MARPAUNG², PARTOMUAN SIMANJUNTAK ${ }^{5,6}$, \\ MUHAMMAD PANDAPOTAN NASUTION ${ }^{7}$
}

\begin{abstract}
${ }^{1}$ Department of Agrotechnology, Faculty of Agriculture, University of Graha Nusantara, Tor Simarsayang, Padangsidimpuan 22712, Indonesia. ${ }^{2}$ Department of Chemistry, Faculty of Mathematic and Natural Science, University of Sumatera Utara, Padang Bulan, Medan 20155, Indonesia. ${ }^{3}$ Department of Pharmacology, Stemcell Centre, University of Sumatera Utara, Medan Indonesia. ${ }^{4}$ Department of Pharmacology, Nanomedicine Center, University of Sumatera Utara, Medan, Indonesia. ${ }^{5}$ Department of Pharmacology, Faculty of Pharmacy, University of Pancasila, Srengseng Sawah, Jagakarsa, Jakarta 12630, Indonesia. ${ }^{6}$ Department of Pharmacology, Research Centre for Biotechnology, Indonesian Institue of Science, Jln. Raya Bogor Km 46, Cibinong 16911, Indonesia. ${ }^{7}$ Department of Pharmacology,

Faculty of Pharmacy, University of Sumatera Utara, Padang Bulan, Medan 20155, Indonesia. Email: misriyanty@gmail.com
\end{abstract}

Received: 27 July 2017, Revised and Accepted: 27 October 2017

ABSTRACT

Objective: This research was study about phytochemical active phenolic compound from pods of jiringa (Archidendron jiringa (Jack) I. C. Nielsen) and it's antioxidant.

Methods: Pods of jiringa were air dried and macerated with methanol. Extract was evaporated using rotary evaporator, and then, crude extract dissolved with water and partitioned with ethyl acetate. Extracts were evaporated and partitioned again with methanol and n-hexane. Column and preparative chromatography used to separate pure compound. Pure compound as methyl gallate was identificated with data from nuclear magnetic resonances of proton $\mathrm{H}\left({ }^{1} \mathrm{H} \mathrm{NMR}\right)$, NMR of carbon $\left({ }^{13} \mathrm{C} \mathrm{NMR}\right)$, and mass spectrometry (MS). Antioxidant activity of pure compound tested by 1,1-diphenyl-2-picrylhydrazyl method.

Results: We found pure phenolic compound from pods of jiringa as methyl gallate that exists on fraction III-2, and it has high antioxidant activity with inhibition concentration 50 was $3.7576 \mu \mathrm{g} / \mathrm{ml}$.

Conclusions: Pods of jiringa contain of active phenolic compound as methyl gallate that has high antioxidant activity. Therefore, it can be used as a source of natural antioxidant.

Keywords: Antioxidant, Archidendron jiringa, Methyl gallate, Nuclear magnetic resonance.

(C) 2018 The Authors. Published by Innovare Academic Sciences Pvt Ltd. This is an open access article under the CC BY license (http://creativecommons. org/licenses/by/4. 0/) DOI: http://dx.doi.org/10.22159/ajpcr.2018.v11i1.21637

\section{INTRODUCTION}

Methyl gallate has been isolated from Cercis chinensis, Acer truncatum Bunge, Rosa rugosa, Acer barbinerve, Toxicodendron sylvestre, Toona sinensis/Cedrela sinensis, Mangifera indica, Pholiota adipose, Givotia rottleriformis Griff., and Galla rhois [1-3]. The radical scavenging effect of methyl gallate has high activity [4-6]. Methyl gallate is derivative of gallic acid. Methyl gallate possesses wide range biological properties that include inhibitor of herpes simplex virus, antioxidant activity, antimicrobial activity, anti-inflammatory, and cancer chemopreventive effect $[2,7]$.

Archidendron jiringa (Jack) I. C. Nielsen (Fabaceae:Mimosoideae), the jiringa is known as "jengkol" in Indonesia. Jengkol can growth in tropical area like Indonesia. We also can find jiringa in Malaysia and Thailand [8]. There are so many benefits from this plant the young shoots of jiringa can we eat as a vegetable; seeds can we eat with rice before or after processing such as boiling, frying, or add with seasoning $[9,10]$. Jiringa is one of the traditional medicine herbs. The leaves of jiringa used to treat skin disease $[11,12]$. The woods of this plant can be used for handicrafts [13]. The jiringa can growth up to $25 \mathrm{~m}$. The color of its bark is gray and pods are brown or black with red or purple inside. The pods consist of 3-9 beans with diameter $3.5 \mathrm{~cm}$ and thickness $2.0 \mathrm{~cm} \mathrm{[14].}$

Phenolic compounds are very useful for the treatment of various diseases. This class of compounds has high antioxidant activity [15]. Antioxidant compounds can reduce free radicals that can cause various diseases, such as cancer, atherosclerosis, emphysema, and arthritis $[12,16,17]$.
Phenolic compounds of plant can inhibit oxidation in the human body due to it's antioxidant potential [18]. This time, there has been interesting to find natural sources of antioxidant in plants, due to their potential health associated with several degenerative and agingrelated diseases such as cancer and cardio vascular diseases [18-22]. Synthetic antioxidants may have toxic, carcinogenic, and negative effects to human's body. Ascorbic acid is one of the sources of natural antioxidants [20-22]. We use it as a standard in this research.

Jiringa's pods are still a lot of wasted and become garbage. Jiringa's pods show in Fig. 1. In this study, we tried to isolated phenolic compounds from A. jiringa (jack) I. C. Nielsen pods and test it's antioxidant activity. Active compounds were identified using data analysis from nuclear magnetic resonance of proton $\mathrm{H}\left({ }^{1} \mathrm{H}\right.$ NMR $)$, NMR of carbon $\left({ }^{13} \mathrm{C} N M R\right)$, and mass spectrometry (MS). We use 1,1-diphenyl-2-picrylhydrazyl (DPPH) method to identificated antioxidant activity. Therefore, we would like to report isolation and characterization methyl gallate from pods of jiringa (A. jiringa (Jack) I. C. Nielsen) in this paper. Methyl gallate has never been reported from pods of jiringa.

\section{METHODS}

\section{Plant material}

The pods of jiringa were collected from Namorambe village, Deli Serdang, North Sumatra, Indonesia. Identification of plant was done at the Herbarium Bogoriensis, LIPI, Cibinong-Indonesia.

\section{Preparation of the extracts}

The pods of jiringa cut small, made powder, and dried at room temperature. In this experiment, we got powder 4,160 g. Further, 


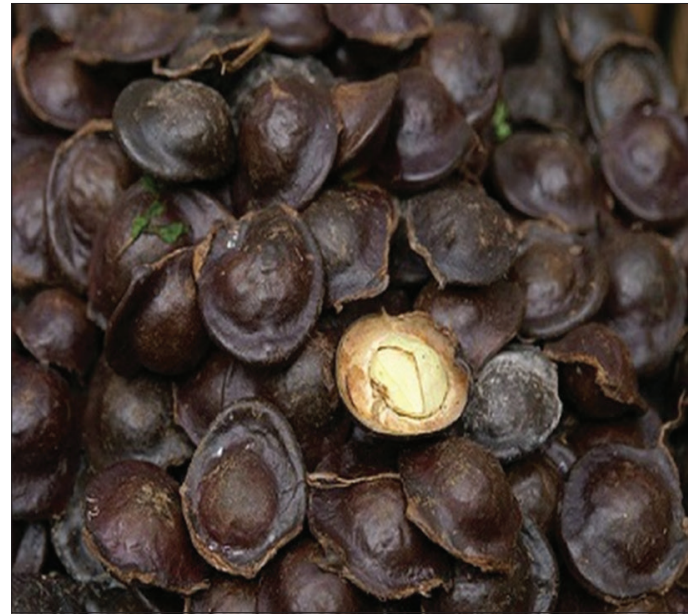

Fig. 1: Pods of Jiringa

powder macerated with methanol $16 \mathrm{l}$. We got methanol extract $140 \mathrm{~g}$. Then, extract was dissolved with water for many times up to $16 \mathrm{l}$ of water. After filtration, the aqueous solution was partitioned with ethyl acetate. Fraction ethyl acetate concentrated in rotary evaporator, same with procedure concentrated methanol extract. We got 37.88 g ethyl acetate extract, dissolved with methanol solvent and partition with $\mathrm{n}$-hexane for many times until n-hexane solvent clearly. We got total phenolic $13.87 \mathrm{~g}$. We use $\mathrm{FeCl}_{3}$ to test phenolic compounds [23].

\section{Separation of compounds}

Total phenolic was subjected to column chromatography silica gel (only $10 \mathrm{~g}$ was subjected) and eluted with chloroform:methanol (chloroform $100 \% ; 9: 1 ; 8: 2 ; 7: 3 ; 6: 4$; and methanol 100\%) to got six fractions.

\section{Purification}

Fraction III (only $200 \mathrm{mg}$ ) purification by preparative chromatography used eluent $\mathrm{CHCl}_{3}$ :ethyl acetate (6:4) and eluted with methanol:ethyl acetate (1:1) with volume $200 \mathrm{ml}$. From preparative chromatography, we obtained six zones. Zone III- 2 cristalizated with aseton and n-hexane to got pure compound.

\section{Identification of pure compound}

Structure pure compound from sample was determined by data from NMR of proton $\mathrm{H}\left({ }^{1} \mathrm{H}\right.$ NMR), NMR of carbon $\left({ }^{13} \mathrm{C} N M R\right)$, and MS.

\section{Antioxidant activity test}

We use DPPH to test antioxidant activity of pure compound from sample. The DPPH solution was made from $7.9 \mathrm{mg}$ DPPH (BM 394.32) weighed then dissolved with methanol proanalysis up to $50 \mathrm{ml}$ and placed in a dark bottle. Subsequently, the blank solution was prepared from $1 \mathrm{ml}$ of $0.4 \mathrm{mM}$ DPPH solution into $5 \mathrm{ml}$ test tube then added methanol proanalysis until the mark and homogenized. The tube was covered with aluminum foil. A total of $5 \mathrm{mg}$ sample were weighed and then dissolved into $10 \mathrm{ml}$ methanol proanalysis $(500 \mu \mathrm{g} / \mathrm{ml})$, this solution was the mother liquor. A total of $50,100,150,200$, and 250 $\mu \mathrm{l}$ of mother liquor were piped into $5 \mathrm{ml}$ tapered test tube to obtain concentrations of $5,10,15,20$, and $25 \mu \mathrm{g} / \mathrm{ml}$. Into each tube was added $1 \mathrm{ml}$ of $1 \mathrm{mM}$ DPPH solution and added with methanol proanalysis up to $5 \mathrm{ml}$, then homogenized. The tube was covered with aluminum foil. Vitamin C solution made from $5 \mathrm{mg}$ of Vitamin $\mathrm{C}$ and then dissolved into $10 \mathrm{ml}$ methanol proanalysis $(500 \mu \mathrm{g} / \mathrm{ml})$, this solution was the mother liquor. A total of $50,100,150,200$, and $250 \mu \mathrm{l}$ of mother liquor were piped into $5 \mathrm{ml}$ tapered test tube to obtain concentrations of 5, 10, 15, 20 , and $25 \mu \mathrm{g} / \mathrm{ml}$. Into each tube was added $1 \mathrm{ml}$ of $1 \mathrm{mM} \mathrm{DPPH}$ solution and added with methanol proanalysis up to $5 \mathrm{ml}$, then homogenized. The tube is covered with aluminum foil. The test solution with some concentration was incubated in a $37^{\circ} \mathrm{C}$ water bath for $30 \mathrm{~min}$. The absorption of the solution was measured at a maximum absorption wavelength of $515 \mathrm{~nm}$ using ultraviolet-visible.

\section{RESULTS AND DISCUSSION}

Identification of jiringa as a sample in this research was done at the Herbarium Bogoriensis, LIPI, Cibinong-Indonesia. The result of plant identification was A. jiringa (Jack) I. C. Nielsen.

The methyl gallate was founded from A. jiringa (Jack) I. C. Nielsen. First, we macerated sample with methanol, further tested using qualitative test $\left(\mathrm{FeCl}_{3}\right.$ test). The $\mathrm{FeCl}_{3}$ test showed that phenolic compounds are existed over there. It probes the color of sample extract is black. Then, we isolated methyl gallate from A. jiringa (Jack) I. C. Nielsen.

Subsequently, we identified methyl gallate with data from NMR of proton H and NMR of carbon, support with MS. We found six fractions in this experiment. From fraction III-2, we found methyl gallate as creamy white crystal. Data NMR of proton $\mathrm{H}$ pure compound is shown in Fig. 2. The peak at $\delta 7.04$ shown two protons $(\mathrm{H})$ at position 2 and $6, \delta 3.81$ shown $\mathrm{H}$ bounded with $\mathrm{OCH}_{3}$. This data NMR of proton $\mathrm{H}$ was compared with data NMR of proton $\mathrm{H}$ methyl gallate was isolated from mushroom (Pholiota adiposa). The peaks of proton $\mathrm{H}$ methyl gallate from mushroom (P. adiposa) were at $\delta 7.04$ shown two protons $(\mathrm{H})$ at position 2 and $6,83.79$ shown $\mathrm{H}$ bounded with $\mathrm{OCH}_{3}$ [3]. Methyl gallate was isolated from seed coats of $G$. rottleriformis Griff. shown data NMR of proton $\mathrm{H}$ at peak $\delta 7.22$ shown two protons $(\mathrm{H})$ at position 2 and 6 [4]. Data NMR of proton $\mathrm{H}$ isolated methyl gallate from T. sylvestre was shown peak at $\delta 7.1$ and $\delta 3.4$. This peak identification protons $\mathrm{H}$ at position 2 and 6, $\mathrm{H}$ bounded with $\mathrm{OCH}_{3}[6]$. This data also agreement with Cheng et al. had been isolated methyl gallate from Chinese toon. Data NMR of proton $\mathrm{H}$ from methyl gallate isolated from Chinese toon shown peak at $\delta 7.02$ and $\delta 3.79$. This peak also identification protons $\mathrm{H}$ at position 2 and $6, \mathrm{H}$ bounded with $\mathrm{OCH}_{3}[24]$.

Further, Data NMR of carbon shown in Fig. 3. The peaks at $\delta 169.1$ identificated carbon at position - $\mathrm{COOH}, \delta 146.6$ (position carbon at 3 and 5), $\delta 139.87$ (position carbon at 4), $\delta 121.49$ (position carbon at 1), $\delta 110.09$ (position carbon at 2 and 6), and $\delta 49.27\left(-\mathrm{OCH}_{3}\right)$ were strong evidence the methyl gallate was found, according to data NMR of carbon methyl gallate had isolated from mushroom (P. adiposa), seed coats of G. rottleriformis Griff., T. sylvestre, and Chinese toon. Data NMR of carbon methyl gallate had isolated from mushroom (P. adiposa) was peaks at $\delta 168.99$ identificated carbon at position - $\mathrm{COOH}, \delta 146.34$ (position carbon at 3 and 5), $\delta 139.66$ (position carbon at 4), $\delta 121.38$ (position carbon at 1), $\delta 110.00$ (position carbon at 2 and 6 ), and 852 ., $\left(-\mathrm{OCH}_{3}\right)$. Data NMR of carbon methyl gallate had isolated from seed coats $G$. rottleriformis Griff. was peaks at $\delta 167.01$ identificated carbon at position - $\mathrm{COOH}, \delta 143.98$ (position carbon at 3 and 5), $\delta 136.61$ (position carbon at 4), $\delta 119.87$ (position carbon at 1), and $\delta 108.14$ (position carbon at 2 and 6). Data NMR of carbon methyl gallate had isolated from seed coats T. sylvestre was peaks at $\delta 167.3$ identificated carbon at position - $\mathrm{COOH}, \delta 146.1$ (position carbon at 3 and 5), $\delta 138.8$ (position carbon at 4), $\delta 121.9$ (position carbon at 1), $\delta 109.9$ (position carbon at 2 and 6), and $\delta 52.0\left(-\mathrm{OCH}_{3}\right)$. Data NMR of carbon methyl gallate had isolated from seed coats Chinese toon was peaks at $\delta 167.8$ identificated carbon at position - $\mathrm{COOH}, \delta 145.3$ (position carbon at 3 and 5), $\delta 138.6$ (position carbon at 4), $\delta 120.2$ (position carbon at 1 ), $\delta 108.8$ (position carbon at 2 and 6$)$, and $\delta 51.1\left(-\mathrm{OCH}_{3}\right)[3,4,6,24]$.

Strong evidence of fraction III-2 was methyl gallate also confirmed by Mass Spectrometry data in Fig. 4 shown 185.35 [M+H]. Molecular weight of methyl gallate is $184 \mathrm{~g} / \mathrm{mol}$ and molecular formula is $\mathrm{C}_{8} \mathrm{H}_{8} \mathrm{O}_{5}[4,25]$.

Based on data NMR of proton H $\left({ }^{1} \mathrm{H}\right.$ NMR), NMR of carbon $\left({ }^{13} \mathrm{C} N M R\right)$, and MS, pure compound isolated from pods of jiringa was determined as methyl gallate. Structure pure compound isolated from pods of jiringa shown in Fig. 5. This study was reported methyl gallate from pods of jiringa for the first time. 


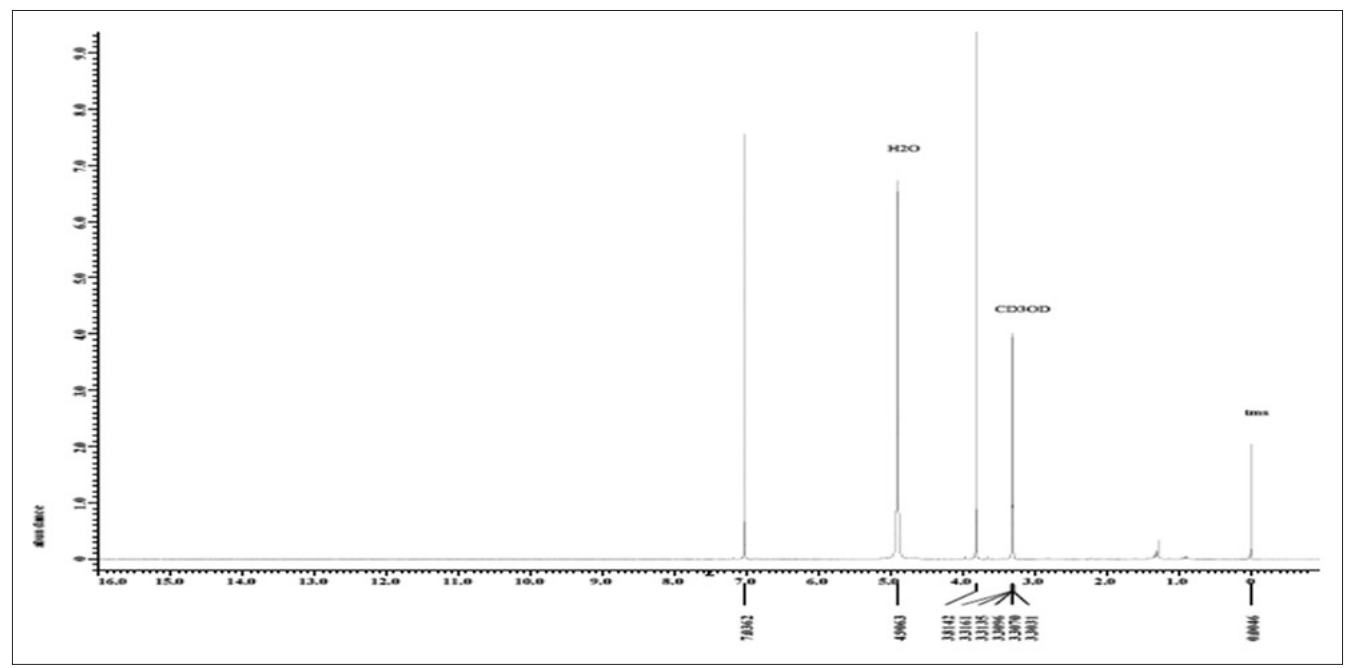

Fig. 2: Data nuclear magnetic resonance of proton $\mathrm{H}\left({ }^{1} \mathrm{H}\right.$ NMR) from pure compound

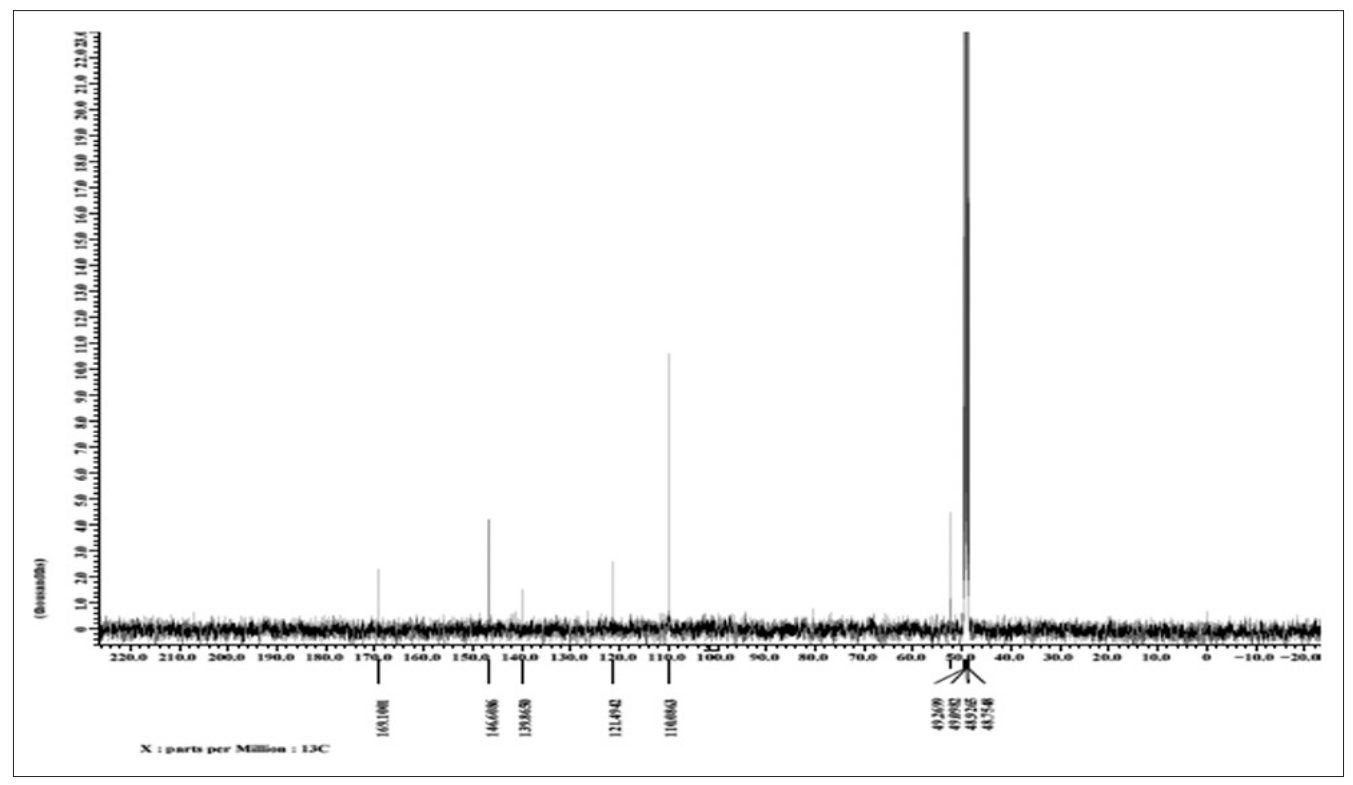

Fig. 3: Data nuclear magnetic resonance of carbon $\left({ }^{13} \mathrm{C} \mathrm{NMR}\right)$ from pure compound

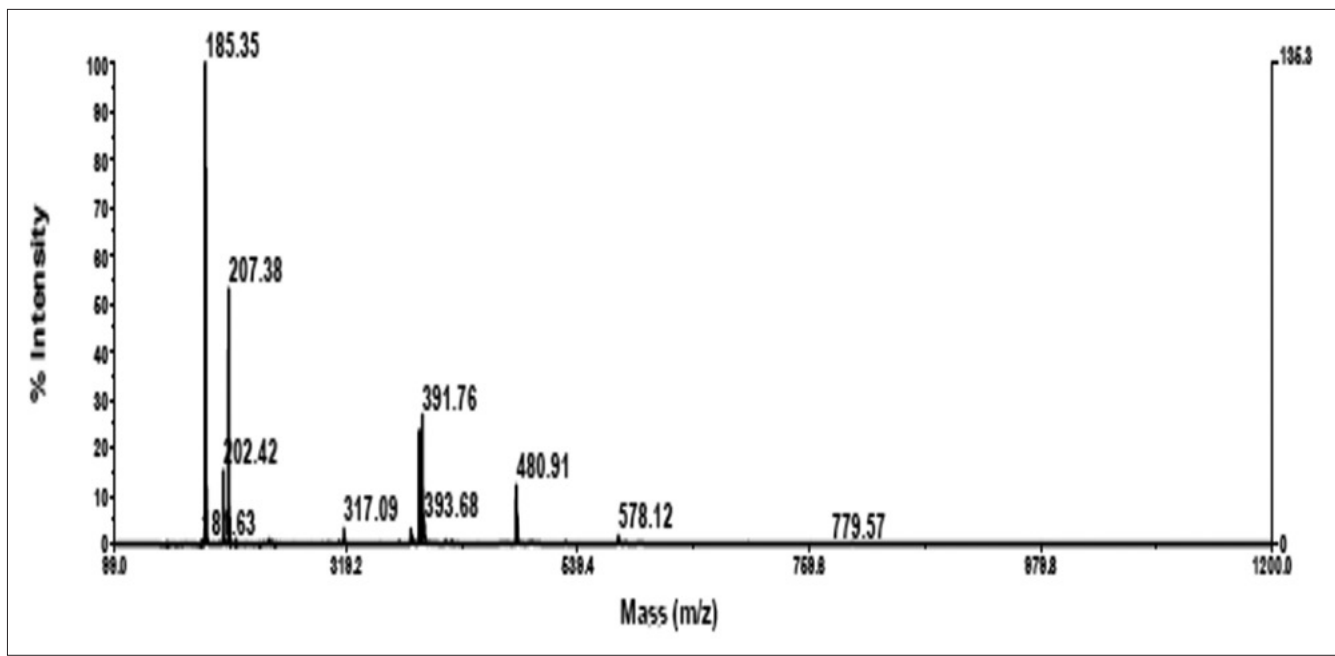

Fig. 4: Mass spectrometry data of pure compound 
Table 1: DPPH scavenging capacities

\begin{tabular}{|c|c|c|c|c|}
\hline Sample & $\begin{array}{l}\text { Concentration } \\
(\mu \mathrm{g} / \mathrm{ml})\end{array}$ & $\begin{array}{l}\text { Absorbance of the first } \\
\text { measurement }\end{array}$ & $\begin{array}{l}\text { Absorbance of the second } \\
\text { measurement }\end{array}$ & Inhibition (\%) \\
\hline \multirow[t]{5}{*}{ Methyl gallate } & 5 & 0.4960 & 0.4960 & $47.65 \pm 0$ \\
\hline & 10 & 0.3801 & 0.3804 & $59.87 \pm 0.000212$ \\
\hline & 15 & 0.2254 & 0.2271 & $76.12 \pm 0.001202$ \\
\hline & 20 & 0.2243 & 0.2261 & $76.23 \pm 0.001273$ \\
\hline & 25 & 0.1980 & 0.2001 & $78.99 \pm 0.001485$ \\
\hline \multirow{5}{*}{$\begin{array}{l}\text { Ascorbic acid } \\
\text { (Vitamin C) }\end{array}$} & & 0.4366 & 0.4924 & $50.98 \pm 0.039457$ \\
\hline & 10 & 0.2980 & 0.2521 & $70.97 \pm 0.032456$ \\
\hline & 15 & 0.2767 & 0.1137 & $79.40 \pm 0.115258$ \\
\hline & 20 & 0.1030 & 0.2004 & $83.99 \pm 0.068872$ \\
\hline & 25 & 0.0120 & 0.0574 & $96.34 \pm 0.032103$ \\
\hline
\end{tabular}

Values are expressed as mean \pm SD, SD: Standard deviation

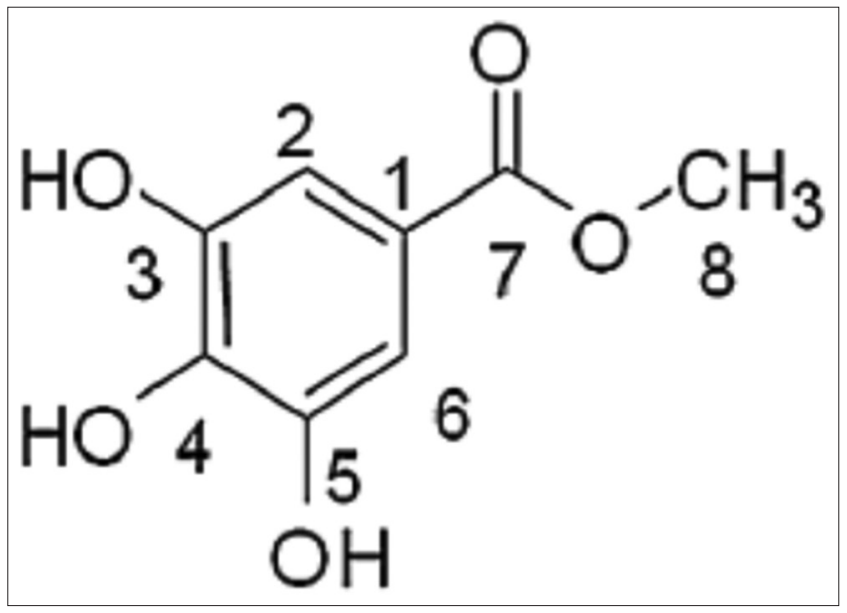

Fig. 5: Structure pure compound as methyl gallate

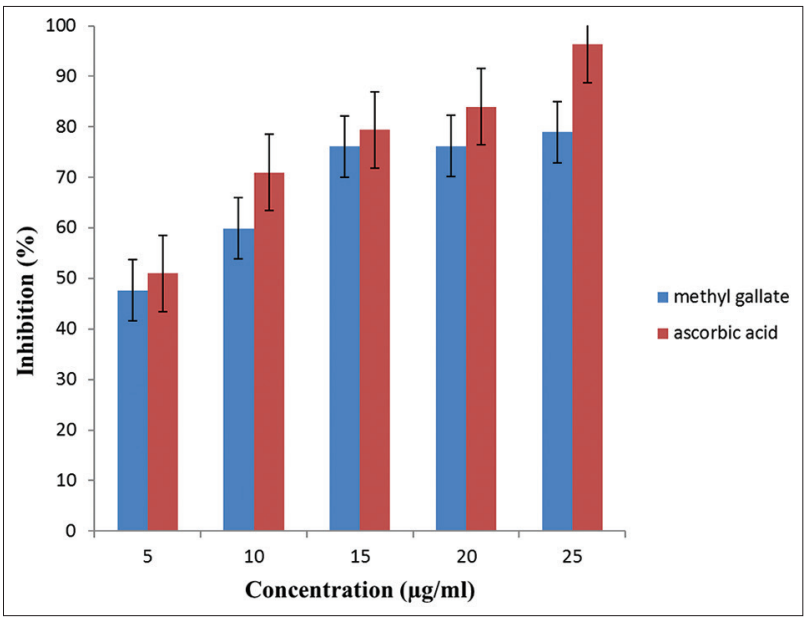

Fig. 6: Inhibition (\%) from various concentrations of methyl gallate in comparison with ascorbic acid

Pure compound as methyl gallate isolated from pods of jiringa exhibited high DPPH activity (Table 1). Methyl gallate is one of the phenolic compounds. Phenolic compounds are the main antioxidant constituents of jiringa's pods. The phenolic compounds are known as powerful chain-breaking antioxidant, and it is very important plant constituents due to their scavenging ability due to their hydroxyl group and may contribute directly to antioxidant action.

Various concentrations of pure compound and ascorbic acid were added into DPPH solution to initiate the reaction.

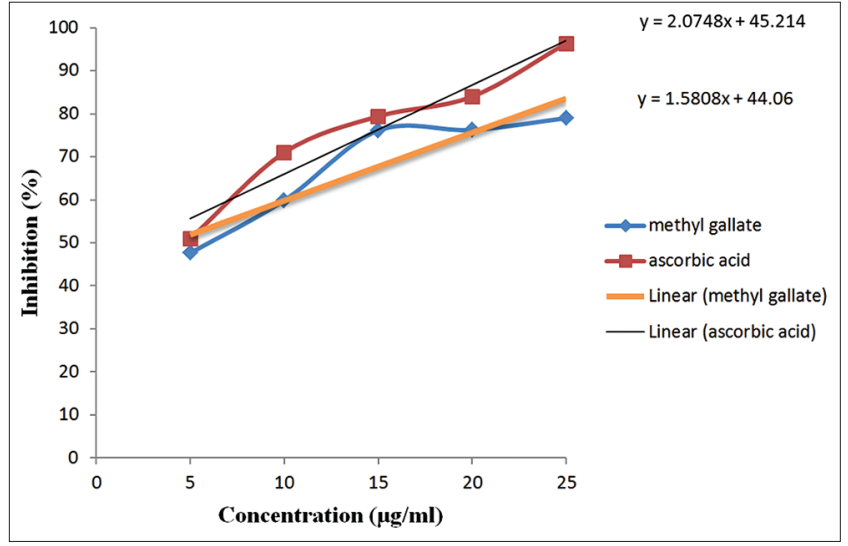

Fig. 7: Linear regression of methyl gallate and ascorbic acid to obtain the value of inhibition concentration $\left(\mathrm{IC}_{50}\right)$

Analysis was performed in duplicate for each concentration of pure compound and ascorbic acid. Comparing \% inhibition methyl gallate and ascorbic acid shown in Fig. 6.

Antioxidant activity of pure compound from jiringa's pods was relatively high when compared to ascorbic acid. The antioxidant activity can be obtained by calculating the value of $\%$ inhibition from sample and blank absorbance.

The percentage of inhibition is calculated by the following formula 1 below: $[26,27]$

$\%$ inhibition $=$

$\frac{\text { Absorbance of blank }- \text { Absorbance of sample }}{\text { Absorbance of blank }} \times 100 \%$

The value of $\mathrm{IC}_{50}$ is the concentration of antioxidant $(\mu \mathrm{g} / \mathrm{ml})$ that can inhibit $50 \%$ free radicals. We used linear regression equation in Fig. 7 to obtain the $\mathrm{IC}_{50}$ value. The value of $\mathrm{IC}_{50}$ is obtained from the intersection of line between $50 \%$ barrier power with concentration axis, then substituted value of $y=50$ to linear regression equation $y=a x+b$. The value of $x$ denotes the value of $\mathrm{IC}_{50}$. The $\mathrm{IC}_{50}$ of methyl gallate calculated from linear regression equation $(y=1.5808 x+44.06)$ was obtained $3.7576 \mu \mathrm{g} / \mathrm{ml}$. In the other hand, the $\mathrm{IC}_{50}$ of ascorbic acid as a standard in this research, calculated from linear regression equation $(2.0748 \mathrm{x}+45.214)$ was obtained $2.3067 \mu \mathrm{g} / \mathrm{ml}$.

According to standard value $\mathrm{IC}_{50}$, sample with $\mathrm{IC}_{50}<50 \mu \mathrm{g} / \mathrm{ml}$, it had very strong antioxidant. Sample with $50 \mu \mathrm{g} / \mathrm{ml}<\mathrm{IC}_{50}<100 \mu \mathrm{g} / \mathrm{ml}$, it had strong antioxidant. Sample with $101 \mu \mathrm{g} / \mathrm{ml}<\mathrm{IC}_{50}<150 \mu \mathrm{g} / \mathrm{ml}$, it had medium antioxidant. Sample with $\mathrm{IC}_{50}>150 \mu \mathrm{g} / \mathrm{ml}$, it had weak antioxidant $[15,28]$. 


\section{CONCLUSIONS}

Based on data spectral NMR 1 dimension proton $\mathrm{H}$ and carbon $\left({ }^{1} \mathrm{H}\right.$ NMR and ${ }^{13} \mathrm{C}$ NMR), supported by MS data, pure compound from fraction III2 was determined as methyl gallate and shows very high antioxidant activity with $\mathrm{IC}_{50} 3.7576 \mu \mathrm{g} / \mathrm{ml}$. This study demonstrated that jiringa's pods are a good source of natural antioxidant. Pure compound showed strong activity in the DPPH assay. The plant has a potential source for bioactive substances that supports several pharmaceutical uses and therapeutic value.

\section{ACKNOWLEDGMENTS}

We thank to Herbarium Bogoriensis of The Research Centre for Biology, Indonesian Institute of Sciences (LIPI), Cibinong, Indonesia, for the botanical identification of jiringa's plant that used in this research.

\section{REFERENCES}

1. Nithitanakool S, Pithayanukul P, Bavovada R. Antioxidant and hepatoprotective activities of thai mango seed kernel extract. Planta Med 2009;75:1118-23.

2. Nakamura ES, Kurosaki F, Arisawa M, Mukainaka T, Takayasu J, Okuda $\mathrm{M}$, et al. Cancer chemopreventive effects of a Brazilian folk medicine, Juca, on in vivo two-stage skin carcinogenesis. J Ethnopharmacol 2002;81:135-7.

3. Wang CR, Zhou R, Ng TB, Wong JH, Qiao WT, Liu F, et al. First report on isolation of methyl gallate with antioxidant, anti-HIV-1 and HIV-1 enzyme inhibitory activities from a mushroom (Pholiota adiposa). Environ Toxicol Pharmacol 2014;37:626-37.

4. Kamatham S, Kumar N, Gudipalli P. Isolation and characterization of gallic acid and methyl gallate from the seed coats of Givotia rottleriformis griff. And their anti-proliferative effect on human epidermis carcinoma A431 cells. Toxicol Rep 2015;2:520-9.

5. Chae HS, Kang OH, Choi JG, Oh YC, Lee YS, Brice OO, et al. Methyl gallate inhibits the production of interleukin- 6 and nitric oxide via down-regulation of extracellular-signal regulated protein kinase in RAW 264.7 cells. Am J Chin Med 2010;38:973-83.

6. Yuan GQ, Li QQ, Qin J, Ye YF, Lin W. Isolation of methyl gallate from Toxicodendron sylvestre and its effect on tomato bacterial wilt. Plant Dis 2012;96:1143-7.

7. Lee SH, Kim JK, Kim DW, Hwang HS, Eum WS, Park J, et al. Antitumor activity of methyl gallate by inhibition of focal adhesion formation and akt phosphorylation in glioma cells. Biochim Biophys Acta 2013;1830:4017-29.

8. Lim TK. Edible Medicinal and Non-Medicinal Plants. Vol. 2. Heidelberg, London, New York: Springer Dordrecht; 2012. p. 544-8.

9. Ashuwini S, Alias A, Karim, Rajeev B. Pithecellobium jiringa legume flour for potential food applications: Studies on their physico-chemical and functional properties. Food Chem 2012;130:528-35.

10. Ruzilawati AB, Imran A, Shaida FS. Effect of Pithecellobium jiringa as antimicrobial agent. Bangladesh J Pharmacol 2012;7:131-4.
11. Mohammad AC, Nik NN, Setianto WB, Mohammad OA. Supercritical Carbon Dioxide Extraction of Constituents of Pithecellobium jiringa Seeds and Their Identification Using Time of Flight Gas Spectrometry. Proceedings of the $1^{\text {st }}$ International Conference on Natural Resources Engineering and Technology $24-25^{\text {th }}$ July 2006; Putrajaya, Malaysia 2006. p. 616-25.

12. Fonseca JC, Barbosa MA, Silva IC, Duarte-Almeida JM, Castro AH, Santos LA. Antioxidant and allelopathic activities of Smilax brasiliensis Sprengel (Smilacaceae). South Afr J Bot 2017;111:336-40.

13. Charungchitrak S, Petsom A, Sangvanich P, Karnchanatat A. Antifungal and antibacterial activities of lectin from the seeds of Archidendron jiringa Nielsen. Food Chem 2011;126:1025-32.

14. Muslim N, Abdul MA. Pithecellobium jiringa: A traditional medicinal herb. Webmed Central Complementary Medicine (WMC001371) 2010;1(12):1-4.

15. Irda F, Evelyne N, Komar RW. In vitro antioxidant activities, total flavonoid, phenolic and carotenoid content from various extracts of four species Asteraceae Herb. Int J Pharm Pharm Sci 2017;7:192-7.

16. Sethupandian G, Kokkaiah I, Palanichamy M. Evaluation of antioxidant and free radical scavenging activities of different solvent extracts of leaves of Piper umbellatum. Asian J Pharm Clin Res 2017;10:274-6.

17. Saswati B, Sukhendu M, Debarati P, Alok KH, Madhubrata C. HPLC phenolic compounds, antioxidant and antimicrobial activity of bulbs from three ornitogalum species available in India. Int J Pharm Pharm Sci 2016;8:187-92

18. Amarowicz R, Shahidi F. Antioxidant activity of broad bean seed extract and its phenolic composition. J Funct Foods 2017;38:656-662.

19. Bharti B, Neha S, Rita K. Gallic acid: A versatile antioxidant with promising therapeutic and industrial applications. R Soc Chem 2015;5:27540-57.

20. Baydar NG, Ozkanb G, Yasar S. Evaluation of the antiradical and antioxidant potential of grape extracts. Food Control 2007;18:1131-6.

21. Tomás-Barberán FA, Andrés-Lacueva C. Polyphenols and health: Current state and progress. J Agric Food Chem 2012;60:8773-5.

22. Andreata RH. New species of Smilax and a key to all species from Minas Gerais, Brazil. Syst Bot 2009;34:28-31.

23. Khoddami A, Wilkes MA, Roberts TH. Techniques for analysis of plant phenolic compounds. Molecules 2013;18:2328-75.

24. Cheng KW, Yang RY, Tsou SC, Clive SC, Lo HC, Lee TC, et al. Analysis of antioxidant activity and antioxidant constituents of Chinese toon. J Funct Food 2009;1:253-9.

25. Lim YA, Mei MC, Kusumoto IT, Miyashiro H, Hattori M, Gupta MP, et al. HIV-1 reverse transcriptase inhibitory principles from Chamaesyce hyssopifolia. Phytother Res 1997;11:22-7.

26. Saranya D, Sekar J, Adaikala RG. Assessment of antioxidant activities, phenol and flavonoid contents of different extracts of leaves, bark and root from the Abutilon indicum (L.) sweet. Asian J Pharm Clin Res 2017;10:88-94.

27. Manal, Mortady H, Mona A, Motagally M, Wafaa SA. Antioxidant potential, antitumor activity and phenolic profile of Phoenix dactylivera Linn. Int J Pharm Pharm Sci 2017;9:130-6.

28. Blois MS. Antioxidant determination by the use of stable free radicals. Nature 1958;181:1199-2000. 